\title{
COLOR STABILITY OF WEATHERED HEAT-TREATED TEAK WOOD
}

\author{
Rosilei Aparecida Garcia ${ }^{1, \star}$, Juliana de Oliveira Lopes ${ }^{2}$, \\ Alexandre Miguel do Nascimento ${ }^{3}$, João Vicente de Figueiredo Latorraca ${ }^{4}$
}

\begin{abstract}
This study investigated the color stability in a heat treatment of teak wood (Tectona grandis) exposed to ultraviolet radiation under accelerated aging conditions. Nine trees from three different spacing levels were used. Samples of $150 \mathrm{~mm}$ x $75 \mathrm{~mm}$ x $20 \mathrm{~mm}$ were prepared and divided into two groups: heartwood and sapwood. Two levels of heat treatment $\left(180\right.$ and $\left.200^{\circ} \mathrm{C}\right)$ were used. The color was measured every 42 hours with a portable spectrophotometer using the CIE-Lab system. Accelerated aging was performed in a QUV/Spray chamber. The total cycle of exposure to ultraviolet radiation was of 168 hours at $340 \mathrm{~nm}$. Tree planting spacing had no effect on color change after ultraviolet radiation. Untreated sapwood had greater color change than untreated heartwood. However, after heat treatment, sapwood showed high color stability, especially at a temperature of $180^{\circ} \mathrm{C}$.
\end{abstract}

Keywords: CIE-Lab system, heat treatment, ultraviolet radiation.

\section{INTRODUCTION}

The exposure of wood to indoors and especially outdoors conditions, makes it susceptible to a number of conditions which undertake its natural durability and leads to natural degradation. The main factors contributing to the natural degradation of wood are moisture, sunlight, heat/cold, abrasion caused by wind, other materials or biological agents, which may act alone or in combination (Williams 2005).

The wood, when exposed to sunlight, intensively absorbs solar radiation and undergoes a photochemical degradation due to ultraviolet rays (UV), which undertake its aesthetic appearance, thereby becoming pale or grayish, yellowish or darkened, depending on the influence of its chemical composition, especially from the extractive compounds (Chang et al. 1982, Feist 1983, Ayadi et al. 2003). This process is called photooxidation or photochemical degradation of the wood surface (photobleaching).

In the process of wood photodegradation, the first phenomenon observed is the color change, followed by the loss of fibers and surfaces erosion. The erosion process is slow and depends on several factors such as anatomy of wood, density, proportion of earlywood and latewood, grain angle and angle of exposure (Williams 2005). The wood photodegradation is a superficial phenomenon since the large amount of chromophoric groups or systems of components distributed on the wood surface prevent the light input. The visible light penetrates into a greater depth in the wood $(200 \mu \mathrm{m})$ than the UV light $(75 \mu \mathrm{m})$, however, its energy (less than $70 \mathrm{kcal}^{\mathrm{mol}}{ }^{-1}$ ) is insufficient to break the chemical bonds of the wood components and, for this reason, the UV radiation is the most harmful to wood (Hon 2001).

\footnotetext{
'Adjunct Professor. Department of Forest Products, Forest Institute, Federal Rural University of Rio de Janeiro (UFRRJ), Rio de Janeiro. 23890-000. Brazil

${ }^{2}$ Forest Engineer, M.Sc. in Environmental Sciences and Forestry, Department of Forest Products, Forest Institute, Federal Rural University of Rio de Janeiro (UFRRJ),

Rio de Janeiro. 23890-000. BRAZIL

${ }^{3}$ Professor, Dr., Department of Forest Products , Forest Institute, Federal Rural University of Rio de Janeiro (UFRRJ), Rio de Janeiro. 23890-000. Brazil

${ }^{4}$ Associate Professor. Department of Forest Products , Forest Institute, Federal Rural University of Rio de Janeiro (UFRRJ), Rio de Janeiro. 23890-000. Brazil

•Corresponding author: rosileigar@ufrrj.br

Received: 20.07.2012 Accepted: 26.01. 2014
} 
Color change of wood exposed to UV radiation is associated to chemical changes in their components. Cellulose is resistant to photochemical oxidation while lignin is a more susceptible component, undergoing structural changes in the presence of UV light to generate chromophoric groups (Hon 2001). The wood color change by the action of light is related to the production of quinones (extractives which alter the color of the wood) and begins after lignin degradation by oxidation. Thus, hardwoods are considered more resistant to color change than the softwoods due to their lower lignin content (Mitsui and Tsuchikawa 2005).

Wood used in outdoor applications must meet certain quality requirements, since it is susceptible to the action of factors which may cause physical and mechanical losses and, also, aesthetic depreciation of the material. Therefore, the wood must possess high dimensional stability, high durability and attractive aesthetic features (Kokutse et al. 2006). Teak wood (Tectona grandis) possesses all these quality attributes being, therefore, a desirable species to manufacture products with outdoor applications.

In Brazil, the teak plantations are situated in the central-west region, where the species found favorable climatic and edaphic conditions to their development. Due to this climate and the high demand for teak wood, its harvesting cycle was reduced from 80 years, in their home regions, to 15-25 years in Brazil (Tsukamoto Filho et al. 2003). Teak wood from Brazilian plantations are appropriate for furniture, construction and decoration, however, it presents a lighter color and a higher proportion of sapwood. The heartwood teak possesses brown color, high dimensional stability and natural durability due to the presence of two compounds: the caoutchouc responsible for water repellence and the tectoquinone, a natural preservative contained in the cells of timber. However, the sapwood has a lighter color and lower durability than heartwood, being required preservative treatments. Furthermore, the natural color of both sapwood and heartwood can vary depending on silvicultural treatments such as the spacing of tree plantation.

Despite the excellent physical and mechanical properties of the teak wood, it presents important color changes when exposed to UV radiation. According to George et al. (2004), color change of teak wood when exposed to UV radiation is visually perceptible and the contrast of color between heartwood and sapwood is even greater with the aging of wood.

Recent studies have shown that heat treatments can provide greater color stability of the wood when exposed to UV radiation (Vernois 2001, Gouveia 2008), as well as adding greater durability and dimensional stability to the wood. In the case of teak wood, this treatment can be an alternative to improve the durability of sapwood, modify the color of sapwood to meet up with that of heartwood providing a more stable wood color when exposed to UV radiation, thus adding more value to the final product and increasing its competitiveness on the market.

Furthermore, the heat treatment may standardize the color variation of teak wood regardless of the spacing of the tree planting. According to the study by Lopes (2012), the spacing has effect on the formation of the original color of teak wood, occurring variations in color between heartwood and sapwood. The change in wood color may be related to the growth conditions which directly influence the rate of tree growth, and therefore it is needed to accomplish an internal mapping from pith to bark and bottom to top of the tree as well as a chemical analysis of wood. Marinomio (2011) studying the teak wood from plantations of different spacing, concluded that less dense tree planting $(6 \times 2 \mathrm{~m})$ produced denser heartwood and sapwood and the highest extractives content. The author also observed a higher content of extractives to the heartwood when compared to sapwood. Oliveira (2011) found a significant difference between the densities of teak wood with and without extractives, with average values 669 and $631 \mathrm{~kg} / \mathrm{m}^{3}$, respectively. But after applying the heat treatment in the teak wood from three types of spacing $4 \mathrm{~m} \times 2 \mathrm{~m}, 5 \mathrm{~m} \times 2 \mathrm{~m}$ and $6 \mathrm{~m} \times 2 \mathrm{~m}$, under two temperature conditions, $180^{\circ} \mathrm{C}$ and $200^{\circ} \mathrm{C}$, Lopes (2012) concluded that the thermal-rectifier treatments not only provided a greater uniformity to wood pieces containing heartwood and sapwood, being the treatment at $200^{\circ} \mathrm{C}$ the most effective, as well as the pieces showed a color uniformity pattern for the three spacing considered in the study. 
In this context, the main objective of this study was to evaluate the color stability of heat-treated teak wood (Tectona grandis) to UV radiation under accelerated aging conditions.

\section{MATERIAL AND METHODS}

\section{Material and heat treatment}

Nine teak trees (Tectona grandis L. f.), 12 years old, were obtained from a plantation located in the experimental area of the Federal Institute of Education, Science and Technology of Mato Grosso, in Cáceres city, Mato Grosso State, Brazil. Three different levels of spacing among trees were considered: $4 \mathrm{~m} \times 2 \mathrm{~m}$, $5 \mathrm{~m} \times 2 \mathrm{~m}$ and $6 \mathrm{~m} \times 2 \mathrm{~m}$, of which three trees per spacing were collected.

Samples of $150 \mathrm{~mm} \times 75 \mathrm{~mm} \times 20 \mathrm{~mm}$ (length $\mathrm{x}$ width $\mathrm{x}$ thickness) were prepared from the logs and divided into two groups: heartwood and sapwood. Samples were air dried and conditioned at $20^{\circ} \mathrm{C}$ and $65 \%$ relative humidity in a climate chamber until equilibrium moisture content was reached.

The heat treatment was conducted in an laboratory electric muffle furnace, from Linn Elektro Therm, with dimensions of $600 \mathrm{~mm} \times 600 \mathrm{~mm} \times 700 \mathrm{~mm}$ equipped with a control system of temperature and time. The treatment was conducted in four steps at two different temperatures: $180^{\circ} \mathrm{C}$ and $200^{\circ} \mathrm{C}$. The four steps were: (1) heating up the material to $100^{\circ} \mathrm{C}$ for 2 hours; (2) increasing the temperature from $100^{\circ} \mathrm{C}$ to final temperature $\left(180^{\circ} \mathrm{C}\right.$ or $\left.200^{\circ} \mathrm{C}\right)$ for 30 minutes and; (3) treatment time in the selected temperature for 2 hours and 30 minutes; and (4) cooling the material for approximately 1 hour. The initial moisture content of the samples were approximately $8-10 \%$ (based on the oven-dry of the wood).

After heat treatment, samples were reconditioned in a climatic chamber at $20^{\circ} \mathrm{C}$ and with $65 \%$ of relative humidity until equilibrium moisture content for the colorimetric analysis and accelerated aging tests were achieved.

\section{Accelerated aging test}

The accelerated aging test was performed in a QUV Weathering Tester chamber, brand Q-Lab, model QUV/Spray adapted with eight UVA lamps, which simulate sunlight in a wavelength range from 295 to $365 \mathrm{~nm}$, with peak emission at $340 \mathrm{~nm}$. The total cycle of UV exposure was of 168 hours at $0,68 \mathrm{~W} / \mathrm{m}^{2}$ with radiation emission at a wavelength of $340 \mathrm{~nm}$. Color measurements were taken every 42 hours. The conditions and exposure time were determined according to the specifications of the equipment used and based on studies conducted by other researchers (Ayadi et al. 2003, Gouveia 2008, Martins et al. 2001, Costa et al. 2011).

Before UV exposure, the samples were polished with a sequence of sandpaper with 80,150 and 200 grit sizes, then stored in plastic bags and kept under ambient light conditions in order to maintain the newly-polishing and humidity conditions.

During the aging test, the samples were placed vertically with a light inclination in the panel holders, with one side exposed to UVA-340 fluorescent lamps.

\section{Colorimetric analysis}

Colorimetric analysis were carried out on the CIE-L*a*b* space, before and after accelerated aging test with the aid of portable CM-2600d spectrophotometer, version 1.41, from Konica Minolta Sensing, Inc., with aperture diameter of $3 \mathrm{~mm}$ (SAV- small area view), standard illuminant D65, observation angle of 10 degrees and specular component included (SCI). For these measurements, the instrument was calibrated with the black and white standard. For the white calibration, the CM-A145 plate was used. 
The color measurements were taken at two predetermined points, i.e, at $25 \%$ and $50 \%$ of the sample total length, before and after the UV radiation cycles. For each sample, the L* (lightness), a* (red hue) and $b^{*}$ (yellow hue) coordinates were recorded from which the variation of each coordinate after each UV radiation cycle was calculated as follows: $\Delta \mathrm{L}^{*}{ }_{\mathrm{UV}}, \Delta \mathrm{a}^{*}{ }_{\mathrm{UV}}$ and $\Delta \mathrm{b}^{*}{ }_{\mathrm{UV}}$. The variation of each coordinate was determined by the difference between the coordinate values before (time $=0$ hour) and after accelerated aging test (time $=42,84,126$ or 168 hours), as accomplished by other authors (Gouveia 2008, Martins et al. 2011, Costa et al. 2011, Ayadi et al. 2003, Ishiguri et al. 2003, Deka et al. 2008, Oltean et al. 2008, Cucui 2009, Mitsui et al. 2004, Carrilo-Parra 2007).

The total color variation of wood after the UV radiation cycles was also determined using the following equation:

$$
\Delta E * a b_{U V}=\sqrt{\left(\Delta L_{U V}^{*}\right)^{2}+\left(\Delta a_{U V}^{*}\right)^{2}+\left(\Delta b_{U V}^{*}\right)^{2}}
$$

where, $\Delta \mathrm{E}^{*} \mathrm{ab}_{\mathrm{UV}}$ : total variation of wood color after $\mathrm{UV}$ radiation; $\Delta \mathrm{L}^{*}{ }_{\mathrm{UV}}, \Delta \mathrm{a}^{*}{ }_{\mathrm{UV}}$ and $\Delta \mathrm{b}^{*}$ : individual variation of each coordinate $\left(\mathrm{L}^{*}, \mathrm{a}^{*}\right.$ and $\mathrm{b}^{*}$ ) after UV radiation. This variable was calculated according to the definition given by Konica Minolta (1998), following the CIE "Commission Internationale de L'Éclairage" standard (1986) and used by other authors (Gouveia 2008, Martins et al. 2011, Costa et al. 2011, Ayadi et al. 2003, Ishiguri et al. 2003, Deka et al. 2008, Oltean et al. 2008, Cucui 2009, Mitsui et al. 2004, Carrilo-Parra 2007).

\section{Experimental design and statistical analysis}

The STATISTICA 7.0 software was used for all analyses of the color parameters $\left(\Delta \mathrm{E}^{*} \mathrm{ab}_{\mathrm{UV}}, \Delta \mathrm{L}^{*}{ }_{\mathrm{UV}}\right.$, $\Delta \mathrm{a}^{*}{ }_{\mathrm{UV}}$ and $\left.\Delta \mathrm{b}^{*}{ }_{\mathrm{UV}}\right)$. The nonparametric Kruskal-Wallis and Wilcoxon-Mann-Whitney tests were used, once the analysis indicated non-normality even after data transformation.

The Kruskal-Wallis test was applied when the number of treatment was equal or superior to $3(\mathrm{~K}=3)$, in other words, to determine the effect of the spacing ( $4 \mathrm{~m} \times 2 \mathrm{~m}, 5 \mathrm{~m} \times 2 \mathrm{~m}$ and $6 \mathrm{~m} \times 2 \mathrm{~m})$, temperature (control, $180^{\circ} \mathrm{C}$ and $200^{\circ} \mathrm{C}$ ) and time of exposure to UV radiation (42, 84, 126 and 168 hours). When the test was significant, the average test was performed in order to determine the differences among the averages of the ranks of studied variables, at the 0,05 probability level.

The Wilcoxon-Mann-Whitney test was applied when the treatment group was equal to $2(\mathrm{~K}=2)$ to determine the effect of wood group (heartwood and sapwood). The independent variables were: spacing between trees (three levels: $4 \mathrm{~m} \times 2 \mathrm{~m}, 5 \mathrm{~m} \times 2 \mathrm{~m}$ and $6 \mathrm{~m} \times 2 \mathrm{~m}$ ), temperature (three levels: ambient or control, $180{ }^{\circ} \mathrm{C}$ and $200{ }^{\circ} \mathrm{C}$ ) and wood group (two levels: heartwood and sapwood). This experimental design resulted in 18 treatment combinations, with four replications, totaling 72 observations for each time of exposure to UV radiation.

The dependent variables studied were the variation of individual color coordinates $\left(\Delta \mathrm{L}^{*}{ }_{U V}, \Delta \mathrm{a}^{*}{ }_{\mathrm{UV}}\right.$ and $\left.\Delta \mathrm{b}^{*}{ }_{\mathrm{UV}}\right)$ and total color variation $\left(\Delta \mathrm{E}^{*} \mathrm{ab}_{\mathrm{UV}}\right)$ after exposure to $\mathrm{UV}$ radiation. 


\section{RESULTS AND DISCUSSION}

Table 1 presents the average values and the ranks of the color parameters $\left(\Delta \mathrm{L}^{*}{ }_{\mathrm{UV}}, \Delta \mathrm{a}^{*}{ }_{\mathrm{UV}}, \Delta \mathrm{b}^{*}\right.$ UV and $\left.\Delta \mathrm{E}^{*} \mathrm{ab}_{\mathrm{UV}}\right)$ after exposure to UV radiation, obtained by Kruskal-Wallis test.

Table 1. Means of color parameters of teak wood (Tectona grandis) exposed to ultraviolet (UV) radiation.

\begin{tabular}{|c|c|c|c|c|}
\hline $\begin{array}{c}\text { Independent } \\
\text { variables }\end{array}$ & $\Delta \mathrm{L}_{\mathrm{UV}}^{*}$ & $\Delta \mathrm{a}_{\mathrm{UV}}$ & $\Delta \mathrm{b}^{*} \mathrm{UV}$ & $\Delta \mathrm{E}^{*} \mathrm{ab} \mathrm{UV}_{\mathrm{UV}}$ \\
\hline \multicolumn{5}{|c|}{ 1. Spacing between trees $(\mathrm{m})$} \\
\hline $4 \times 2$ & $5,19(285,44) \mathrm{a}$ & $2,30(302,30) \mathrm{a}$ & $4,92(284,98) \mathrm{a}$ & $8,10(288,10) \mathrm{a}$ \\
\hline $5 \times 2$ & $9,93(273,36) \mathrm{a}$ & $1,88(280,91) \mathrm{a}$ & $4,68(278,18) \mathrm{a}$ & $7,68(272,27) a$ \\
\hline \multirow[t]{2}{*}{$6 \times 2$} & $6,36(306,70)$ a & $1,90(282,29) \mathrm{a}$ & $4,52(302,33) \mathrm{a}$ & $8,25(305,14) \mathrm{a}$ \\
\hline & NS & NS & NS & NS \\
\hline \multicolumn{5}{|c|}{ 2. Temperature $\left({ }^{\circ} \mathrm{C}\right)$} \\
\hline $\begin{array}{l}\text { Ambient } \\
\text { (control) }\end{array}$ & $3,78(294,78) b$ & $2,94(359,69) \mathrm{a}$ & $7,74(370,66) \mathrm{a}$ & $10,06(325,57) a$ \\
\hline 180 & $3,41(203,89) \mathrm{c}$ & $1,01(175,53) \mathrm{c}$ & $3,52(236,20) \mathrm{c}$ & $5,22(196,89) b$ \\
\hline \multirow[t]{2}{*}{200} & $5,61(370,29) \mathrm{a}$ & $1,95(333,57) b$ & $3,35(259,13) b$ & $8,76(346,15) \mathrm{a}$ \\
\hline & $\mathrm{S}$ & $\mathrm{S}$ & $\mathrm{S}$ & $\mathrm{S}$ \\
\hline \multicolumn{5}{|c|}{ 3. Time of UV radiation $(\mathrm{h})$} \\
\hline 42 & $4,57(257,87)$ a & $1,92(270,11) a$ & $5,29(290,40) \mathrm{a}$ & $8,25(276,51) a$ \\
\hline 84 & $5,24(288,29) \mathrm{a}$ & $2,10(292,52) a$ & $4,52(268,53) \mathrm{a}$ & $7,87(283,10) \mathrm{a}$ \\
\hline 126 & $5,92(303,75) a$ & $2,12(293,18) a$ & $5,33(295,93) a$ & $8,24(292,86) \mathrm{a}$ \\
\hline \multirow[t]{2}{*}{168} & $5,74(304,09) \mathrm{a}$ & $2,3(298,19) \mathrm{a}$ & $3,19(299,13) \mathrm{a}$ & $8,49(301,52) \mathrm{a}$ \\
\hline & NS & NS & NS & NS \\
\hline
\end{tabular}

$\Delta \mathrm{L}{ }_{\mathrm{UV}}, \Delta \mathrm{a}_{\mathrm{UV}}, \Delta \mathrm{b} *_{\mathrm{UV}}$ : variation of $\mathrm{L} * \mathrm{a} *$ and $\mathrm{b} *$ coordinates after exposure to $\mathrm{UV}$ radiation, respectively. $\Delta \mathrm{E} *$ ab $\mathrm{UV}_{\mathrm{UV}}$ : total color variation after exposure to UV radiation. Values between brackets refer to the means of the ranks made by Kruskal-Wallis test. Means of ranks with the same letter are not significantly different from each other. S: significant at the 0,05 probability level. NS: not significant.

The spacing effect on the color change of teak wood was not significant, i.e., all exhibited the same intensity of discoloration. However, the temperature had a significant effect on color change. The untreated wood (control) was statistically different from heat-treated wood for both temperatures $\left(180^{\circ} \mathrm{C}\right.$ and $\left.200^{\circ} \mathrm{C}\right)$.

The $\Delta \mathrm{a}^{*}{ }_{\mathrm{UV}}, \Delta \mathrm{b}^{*}{ }_{\mathrm{UV}}$ and $\Delta \mathrm{E}^{*} \mathrm{ab}_{\mathrm{UV}}$ ranked the highest averages for untreated wood, with values of 359.69 , 370.66 and 325.57 , respectively, while the treatment at $200^{\circ} \mathrm{C}$ had the highest $\Delta \mathrm{L}^{*}{ }_{\mathrm{UV}}(5,61)$. However, the heat treatment at $180^{\circ} \mathrm{C}$ had the lowest variations of color parameters. This indicates that the heat treatment at $180^{\circ} \mathrm{C}$ provided higher color stability of teak wood. However, when the behavior of heartwood and sapwood is observed alone, it is clear that the heat treatment improved only the color stability of sapwood (Figure 1).

These results are similar to those found by Ayadi et al. (2003) on wood of Fraxinus sp., Fagus sylvatica, Pinus pinaster and Populus sp. heat-treated at $240^{\circ} \mathrm{C}$ for 2 hours. The authors observed significant wood color changes on both untreated and heat-treated woods, after the first 36 hours of exposure to UV radiation, with higher change on treated woods. However, after a total cycle of 835 hours to UV radiation, the heattreated woods had less total color variation than untreated woods. 


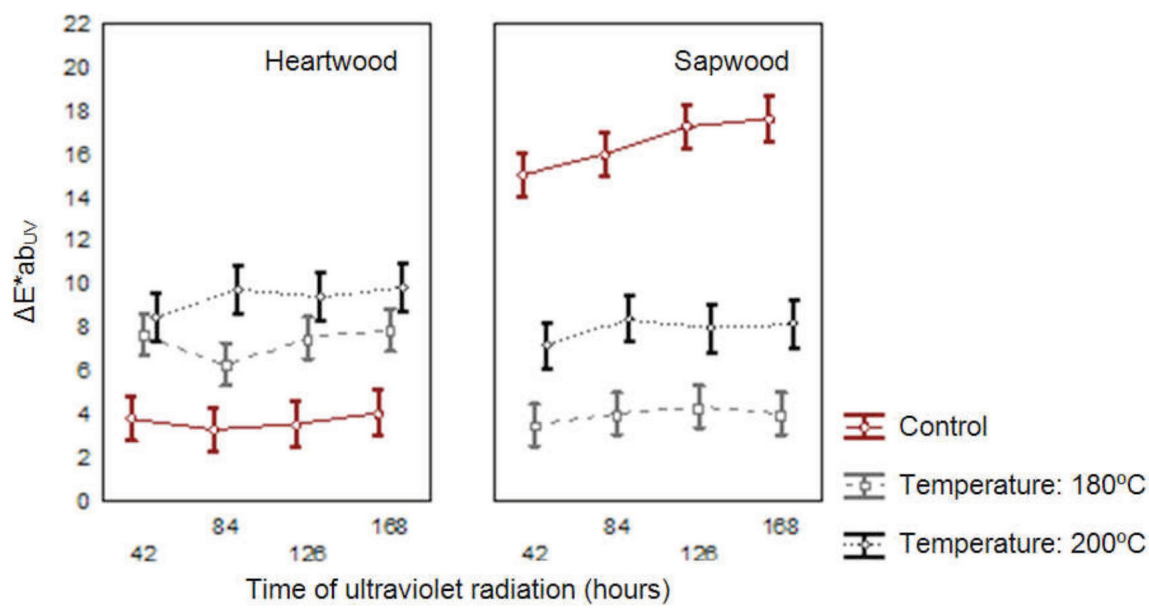

Figure 1. Total color variation of heartwood and sapwood of teak (Tectona grandis) exposed to ultraviolet radiation in accelerated aging conditions.

Furthermore, Gouveia (2008) improved the wood color stabilization of two tropical species marupá (Simarouba amara) and louro-vermelho (Sextonia rubra) after heat treatment. These species, when treated at $150^{\circ} \mathrm{C}$ for 2 hours and at $200^{\circ} \mathrm{C}$ for 1 hour, had greater resistance to photo-discoloration after 84 hours of UV radiation exposure. However, the same treatment was not efficient to prevent wood discoloration of jequitibá-rosa (Cariniana micrantha).

Vernois (2001) observed that the heat-treated wood exposed to UV radiation presented a grayish color, but it also presented small fissures due to the higher dimensional stability and, therefore, a greater performance over time.

According to Ahajji et al. (2009), the best color performance of heat-treated wood can be attributed to the lignin, whose molecule is partially modified during the heat treatment and many phenolic monomers are formed, a phenomenon known as lignin condensation. The lignin condensation partially inhibits the UV light and minimizes the phenoxyl free radical reactions as well as the formation of low molecular weight products, such as quinones, which cause color change. Thus, heat-treated wood has higher resistance to photo-discoloration (Ayadi et al. 2003, Ahajji et al. 2009).

As observed in Table 1, the time of exposure to UV radiation did not affect the color change of teak wood. However, an evident color change was observed after the first cycle of 42 hours of $U V$ radiation exposure (Figure 2). This implies that UV light had early effect on the color between 0 to 42 hours of exposure but thereafter the color remained unchanged. This behavior coincides with those reported in the literature, which indicates that the greatest color changes occur within the first 20 hours of exposure and then it becomes constant after subsequent cycles (Ayadi et al. 2003, Sundqvist 2004, Gouveia 2008, Ahajji et al. 2009). Sundqvist (2004) verified that untreated woods of Picea abies, Pinus silvestres and Betula pubescens had rapid color changes after the first 2 hours of UV light exposure, while the color of heat-treated woods had more resistance to the same conditions. After 100 hours of exposure, both untreated and heat-treated woods presented little change in color. 
A: Heartwood

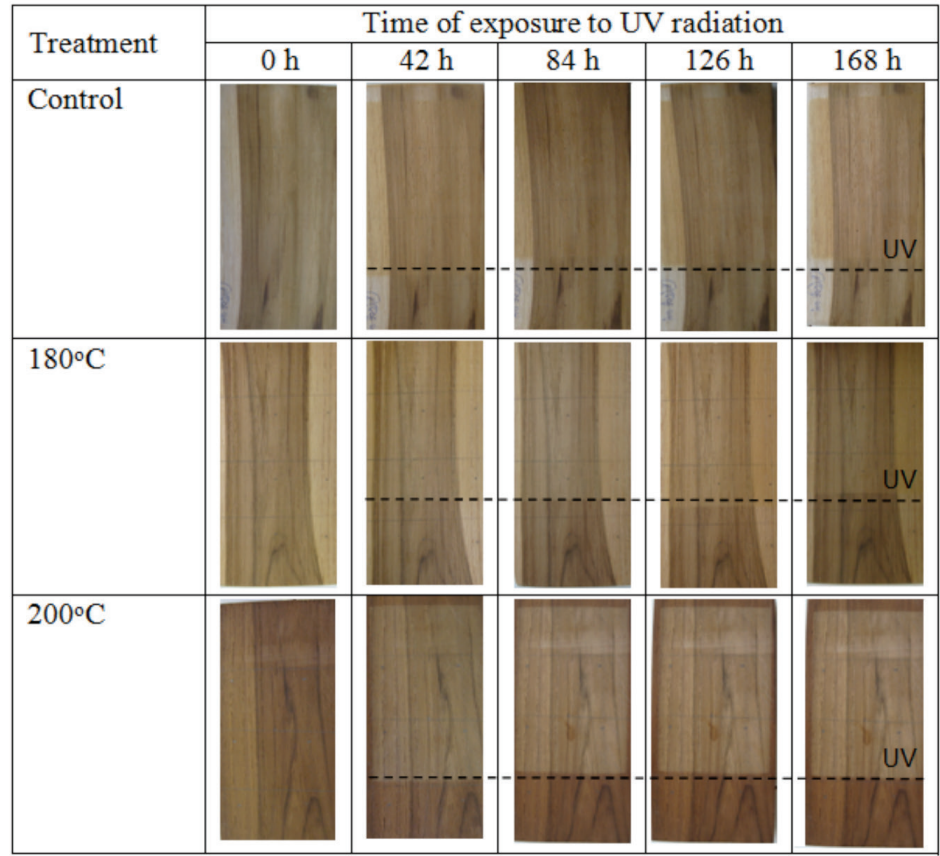

B: Sapwood

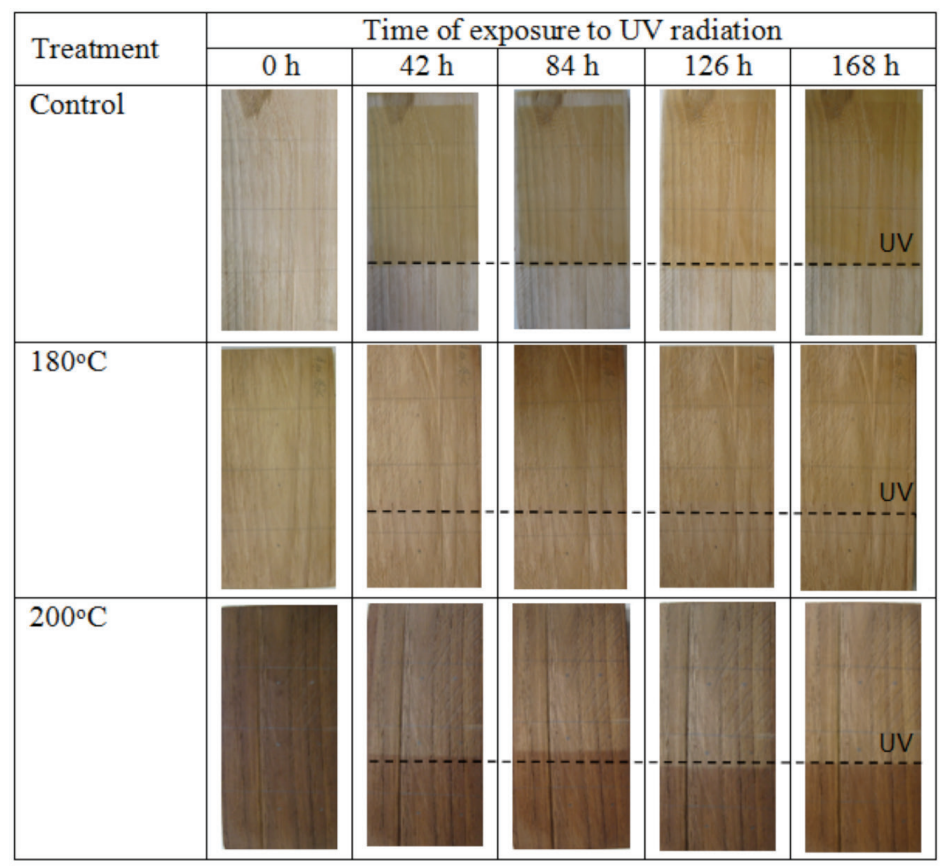

Figure 2. Color change of untreated and heat-treated heartwood and sapwood of teak (Tectona grandis) exposed to ultraviolet (UV) radiation in accelerated aging conditions. The dashed line marks the region exposed to UV radiation. 
Table 2 presents the color parameters average values of heartwood and sapwood exposed to UV light and the ranks obtained by Wilcoxon-Mann-Whitney test. For all color parameters $\left(\Delta \mathrm{L}^{*}{ }_{\mathrm{UV}}, \Delta \mathrm{a}^{*}{ }_{\mathrm{UV}}, \Delta \mathrm{b}^{*}{ }_{\mathrm{UV}}\right.$ and $\Delta \mathrm{E}^{*} \mathrm{ab}_{\mathrm{UV}}$ ), the sums of ranks for untreated sapwood was higher than untreated heartwood. It means that the color of untreated sapwood is more unstable to UV light than untreated heartwood. After aging, untreated sapwood has acquired a yellowish color increasingly over time, visually perceptible, whereas untreated heartwood had a slight discoloration, hardly noticeable (Figure 2). The different behavior between the heartwood and sapwood can be explained by the extractive contents. Barreto and Pastore (2009) evaluated the effect of extractives on the color variation and photodegradation of four tropical woods and verified that yellow and red chromophores formed on the surface of marupá (Simarouba amara), wood characterized by whitish color and lower extractive content $(1,9 \%)$, was higher than those produced on the wood of itaúba (Mezilaurus itauba), which has dark reddish-brown color and higher extractive content (7,2\%). These authors attest that the extractive compounds of itaúba wood probably exhibit a function of protection, since it is degraded first thereby avoiding the lignin degradation. In addition, Marupá species, extractives-free wood, had more formation of yellow and red wood chromophores with extractive compounds, exposed to UV light. This suggests that the extractive compounds have an important participation on the process of wood photodegradation and it depends on its chemical nature.

Table 2. Means of color parameters of teak (Tectona grandis) heartwood and sapwood exposed to ultraviolet (UV) radiation.

\begin{tabular}{|c|c|c|c|c|}
\hline Treatment & Heartwood & Sapwood & $Z$ value & $p$ \\
\hline \multicolumn{5}{|c|}{ Control } \\
\hline$\Delta \mathrm{L}^{*}{ }_{\mathrm{UV}}$ & $2,05(4684)$ & 10,66 (13844) & $-11,89^{*}$ & 0,00 \\
\hline$\Delta \mathrm{a}^{*} \mathrm{UV}$ & $1,16(4692)$ & $4,72(13835)$ & $-11,87^{*}$ & 0,00 \\
\hline$\Delta \mathrm{b}^{*}{ }_{\mathrm{UV}}$ & $2,75(4656)$ & 11,78 (13872) & $-11,96^{*}$ & 0,00 \\
\hline$\Delta \mathrm{E}^{*} \mathrm{ab} \mathrm{b}_{\mathrm{UV}}$ & $3,64(4656)$ & $16,48(13872)$ & $-11,96^{*}$ & 0,00 \\
\hline \multicolumn{5}{|c|}{$180^{\circ} \mathrm{C}$} \\
\hline$\Delta \mathrm{L}^{*} \mathrm{uV}_{\mathrm{UV}}$ & $4,94(15190)$ & $2,15(8245)$ & $7,56^{*}$ & 0,00 \\
\hline$\Delta \mathrm{a}_{\mathrm{UV}}^{*}$ & $1,22(12116)$ & $0,81(11320)$ & $0,86^{\mathrm{NS}}$ & 0,38 \\
\hline$\Delta \mathrm{b}^{*} \mathrm{UV}$ & 3,95 (13806) & $3,09(9629)$ & $4,54 *$ & 0,00 \\
\hline$\Delta \mathrm{E}^{*} \mathrm{ab}_{\mathrm{UV}}$ & $7,08(15045)$ & $3,37(8391)$ & $7,24 *$ & 0,00 \\
\hline \multicolumn{5}{|c|}{$200^{\circ} \mathrm{C}$} \\
\hline$\Delta \mathrm{L}^{*} \mathrm{UV}$ & $7,46(6861)$ & $6,41(6179)$ & $2,11^{*}$ & 0,03 \\
\hline$\Delta \mathrm{a}_{\mathrm{UV}}^{*}$ & $2,53(6768)$ & $2,18(6273)$ & $1,79^{\mathrm{NS}}$ & 0,07 \\
\hline$\Delta \mathrm{b}_{\mathrm{UV}}$ & $3,78(6734)$ & $2,22(6306)$ & $1,68^{\mathrm{NS}}$ & 0,09 \\
\hline$\Delta \mathrm{E}^{*} \mathrm{ab} \mathrm{UV}_{\mathrm{UV}}$ & $9,54(7336)$ & $7,98(5705)$ & $3,71^{*}$ & 0,0002 \\
\hline
\end{tabular}

$\Delta \mathrm{L}^{*}{ }_{\mathrm{UV}}, \Delta \mathrm{a}_{\mathrm{UV}}^{*}, \Delta \mathrm{b}_{\mathrm{UV}}^{*}$ : variation of $\mathrm{L}^{*}, \mathrm{a}^{*}$ and $\mathrm{b}^{*}$ coordinates after exposure to UV radiation, respectively. $\Delta \mathrm{E}^{*} \mathrm{ab}_{\mathrm{UV}}$ : total color variation after exposure to UV radiation. Values between brackets refer to the means of the ranks made by

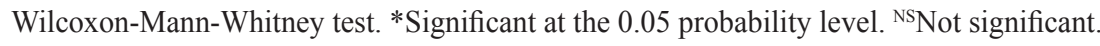

The statistical analysis showed significant difference between rank averages of the color parameters $\left(\Delta \mathrm{L}_{\mathrm{UV}}^{*}, \Delta \mathrm{a}_{\mathrm{UV}}^{*}, \Delta \mathrm{b}_{\mathrm{UV}}^{*}\right.$ and $\left.\Delta \mathrm{E}^{*} \mathrm{ab}_{\mathrm{UV}}\right)$ from heat-treated heartwood and sapwood (Table 2). The treatment at $180^{\circ} \mathrm{C}$ showed significant difference between heartwood and sapwood for all color variables, except to $\Delta \mathrm{a}^{*}{ }_{\mathrm{UV}}$. In this case, the heartwood had higher values of sums of ranks than sapwood. For the treatment at $200^{\circ} \mathrm{C}$, there was significant difference in the lightness $\left(\Delta \mathrm{L}^{*}{ }_{\text {UV }}\right)$ between heartwood and sapwood. It means that in the less aggressive treatment $\left(180^{\circ} \mathrm{C}\right)$, the color change after $\mathrm{UV}$ radiation was more evident between heartwood and sapwood. Furthermore, these results show that the heat treatment provided a higher resistance to the sapwood color change, especially at $180^{\circ} \mathrm{C}$. 


\section{CONCLUSIONS}

The technique used in this study, artificial accelerated aging, allowed to simulate an assessment of the teak wood (Tectona grandis) color changes before and after heat treatment.

The spacing variable did not affect the color change of teak wood (Tectona grandis) exposed to ultraviolet radiation, thus the teak wood (Tectona grandis) presented similar color changes in the considered spacing.

The untreated sapwood suffered more abrupt color changes than untreated heartwood, after UV radiation exposure. However, the use of heat treatment was effective for sapwood since it presented greater resistance to its color change after exposure to ultraviolet radiation comparing to heartwood.

The heat-treated sapwood teak (Tectona grandis) became more resistant to color change after accelerated aging than untreated sapwood, thus the heat treatment is adding more value to this timber, by providing greater stability to its color, besides adding other benefits such as the increase of sapwood durability, thereby enabling its use and exploitation of this reforestation timber.

The heat treatment at $180^{\circ} \mathrm{C}$ was efficient to teak sapwood (Tectona grandis) because it provided the greatest color stability with wood exposure to UV radiation after 168 hours. It is recommended the accomplishment of traditional chemical tests to identify and measure the amount of principal components and extractives before and after heating the woods and after the aging period, for a better understanding of the different behaviors found at heartwood and sapwood teak (Tectona grandis).

Further research should seek to optimize exposure values of temperature and time for new thermal treatment which fetches color stabilization of wood species of industrial interest.

The interest in studies on photostabilizer treatments is increasing because they can be used as a wood protective measure against UV action, aiming, for example, the use of the same furniture for gardens and decks which suffer from weathering due to external agents (humidity, UV, etc.). Thus, photostabilizer treatments can ensure a quality pattern for long-term and add more value to the final product.

\section{REFERENCES}

Ahajji, A.; Diouf, P. N.; Aloui, F.; Elbakali, I.; Perrin, D.; Merlin, A.; George, B. 2009. Influence of heat treatment on antioxidant properties and colour stability of beech and spruce wood and their extractives. Wood Science and Technology 43: 69-83.

Ayadi, N.; Lejeune, F.; Charrier, F.; Charrier, B.; Merlin, A. 2003. Color stability of heat-treated wood during artificial weathering. Holz als Roh und Werkstoff 61: 221-226.

Barreto, C.C.K.; Pastore, T.C.M. 2009. Resistance to artificial weathering of four tropical woods: the effect of the extractives. Ciência Florestal 19 (1): 23-30.

Carrilo-Parra, A. 2007. Technological Investigation of Prosopis Laevigata wood from northeast Mexico.. Thesis (Doctor of Philosophy) - University of Göttingen, Göttingen, 137 p.

Chang, S.T.; Hon, D.N.S.; Feist, W.C. 1982. Photodegradation and photoprotection of wood surfaces. Wood Fiber Science 14 (2): 104-107.

CIE. 1986. Colorimetry, 2nd ed., CIE Publications n. 15.2, Commission Internationale del'Eclairage, Viena.

Costa, J.A.; Gonçalez, J.C.; Camargos, J.A.; Gomes, I.A.S. 2011. Photodegradation of two tropical wood species: jatobá (Hymenaea courbaril) and tauari (Couratari oblongifolia) submitted to ultraviolet radiation (in Portuguese). Cerne 17 (1): 133-139.

Cucuí, I.; Negri, M.; Tessadri, B. 2009. Mid-term color change of finished and non-finished hardwood temperature due to natural and artificial aging. In: 2nd International Scientific Conference on Hardwood Processing, 2009, Paris, France. 8 p. 
Deka, M.; Humar, M.; Rep, G.; Kričej, B.; Šentjurc, M.; Petric, M. 2008. Effects of UV light irradiation in color stability of copper ethanolamine treated thermally modified and non-modified wood: EPR and DRIFT spectroscopic studies. Wood Science and Technology 42: 5-20.

Feist, W.C. 1983. Weathering and protection of wood. In: Annual meeting of the American wood-preservers' association. Kansas 79: 195-205.

George, B.; Suttie, E.; Merlin, A.; Deglise, X. 2004. Photo-degradation and photo-stabilization of wood (State of art). In: COST E 18 Final Seminar, pp. 1-9.

Gouveia, F. N. 2008. Thermal treatments for the colorimetric stabilization of tropical hardwood (in Portuguese). Ph.D. Thesis, Universidade de Brasília, Brasília, Brazil, 130 p.

Hon, D.N.S. 2001. Weathering and photochemistry of wood. In: HON, D. N.-S.; SHIRAISHI, N. (eds) Wood and cellulosic chemistry. Marcel Dekker, New York, pp. 513-546.

Ishiguri, F.; Maruyama, S.; Takahashi, K.; ABE, Z.; YOKOTA, S.; ANDOH, M.; Yoshizawa, N. 2003. Extractives Relating to heartwood color changes in sugi (Crytomeria japonica) by a combination of smoke-heating and UV radiation exposure. J Wood Sci 49: 135-139.

Kokutse, A. D.; Stokes, A.; Baillères, H.; Kokou, K.; Baudasse, C. 2006. Decay resistance of Togolese teak (Tectona grandis L. f.) heartwood and relationship with colour. Trees 20: 219-223.

Konica Minolta Sensing Inc. 1998. Comunicação precisa da cor. 57 p. Japão.

Lopes, J.O. 2012. Uniformity and Stability of Color of the heat-treated Tectona grandis L.f wood. Msc. Dissertation, Federal Rural University of Rio de Janeiro, Rio de Janeiro, Brazil, 81 p

Martins, S. B.; Santos, C. M.; Gonçalez, J. C.; Camargos, J.A. 2011. Accelerated artificial aging by ultraviolet radiation of Eucalyptus benthamii and Pinus caribaea var. hondurensis woods (in Portuguese). Floresta 41 (1): 87-96.

Marinomio, G. B. 2011. Effect of density and extractive content variation in the color of the wood of Tectona grandis L. f. Monograph (Course of Forestry) - Federal Rural University of Rio de Janeiro, Seropédica, $20 \mathrm{p}$.

Mitsui, K.; Murata, A.; Tolvaj, L. 2004. Changes in the properties of light-irradiated wood with heat treatment. Part 3. Monitoring by DRIFT spectroscopy. Holz als Roh-und Werkstoff 62: 164-168.

Mitsui, K.; Tsuchikawa, S. 2005. Low atmospheric temperature dependence on photodegradation of wood. Journal of Photochemistry and Photobiology B: Biology 81: 84-88.

Oliveira, B.R.U. 2011. Dendrochronology and analysis of the radial variation of the density of the wood of trees of Tectona grandis L.f, the city of Cáceres, MT. Dissertation (Master's in Environmental Science and Forestry) - Federal Rural University of Rio de Janeiro, Seropédica, 64 p.

Oltean, L.; Teischinger, A.; Hansmann, C. 2008. Wood surface discolouration due to simulated indoor sunlight exposure. Holz Roh-und Werkstoff 66 51-56.

Sundqvist, B. 2004. Colour Changes an acid formation in wood during heating. Thesis, Luleå University of Technology, Sweden.

Tsukamoto Filho, A.A.; Silva, M.L.; Couto, L.; Müller, M.D. 2003. Economic analysis of a teak plantation submitted to thinning (in Portuguese). Revista Árvore 27 (4): 487-494.

Vernois, M. 2001. Heat treatment of wood in France: state of the art. In: Rapp AO Review on heat treatments of wood. In: Special seminar: environmental optimization of wood protection, Antibes, France, 68 p.

Williams, R.S. 2005. Weathering of wood. In: Rowell, R.M. (ed) Handbook of wood chemistry and wood composites. CRC Press, Florida, pp. 139-185. 